Reviu Akuntansi dan Bisnis Indonesia, Vol. 1 No. 1, Hlm: 68-77, Juli 2017

Website: http://journal.umy.ac.id/index.php/rab

\title{
Pengaruh Tekanan Waktu, Independensi, Skeptisme Profesional, dan Pengalaman Kerja Terhadap Kemampuan Auditor Mendeteksi Kecurangan Pada Laporan Keuangan (Studi pada Empiris Badan Pemeriksa Keuangan Perwakilan Provinsi Daerah Istimewa Yogyakarta)
}

\begin{abstract}
Nurul Hafizhah; Ahim Abdurahim
Program Studi Akuntansi Univeritas Muhammadiyah Yogyakarta.

I N F O A R T I K E L

Kata Kunci:

Tekanan Waktu,

Independensi, Skeptisme

Profesional, Pengalaman

Kerja, dan Kemampuan

Deteksi Auditor.

Jenis Artikel:

Penelitian Empiris

Correspondence:

ahim@umy.ac.id

A B S T R A K

Penelitian ini bertujuan menganalisis pengaruh tekanan waktu, independensi, skeptisisme profesional, dan pengalaman kerja terhadap kemampuan pendeteksian kecurangan laporan keuangan auditor. Subjek dalam penelitian ini yaitu auditor eksternal yang bekerja di Badan Pemeriksa Keuangan Republik Indonesia di Daerah Istimewa Provinsi Yogyakarta. Dalam penelitian ini, sampel 37 responden dipilih menggunakan purposive sampling. Empat puluh lima kuesioner diberikan kemudian tiga puluh tujuh kuesioner dikembalikan dan dapat diperiksa menggunakan model regresi linier berganda. Alat analisis yang digunakan dalam penelitian ini adalah SPSS 22. Berdasarkan analisis yang telah dilakukan hasilnya adalah tekanan waktu berpengaruh negatif terhadap kemampuan deteksi kecurangan auditor. Independensi, skeptisisme profesional, dan pengalaman kerja berpengaruh positif pada kemampuan deteksi kecurangan auditor.
\end{abstract}

(C) 2019 RAB. Published by Universitas Muhammadiyah Yogyakarta

\section{PENDAHULUAN}

Dalam konteks risiko timbulnya kecurangan dapat terjadi pada sektor swasta dan publik. Kasus kecurangan yang sering terjadi seperti penggelapan aset, KKN (korupsi, kolusi, dan nepotisme), manipulasi laporan keuangan, terlebih pada sektor publik dapat dilakukan dalam bentuk kebocoran Anggaran Pendapatan dan Belanja Negara (APBN). Hal tersebut menunjukkan bahwa kasus kecurangan harus segera diatasi, oleh karena itu perlu dilakukan pemeriksaan kewajaran dari suatu laporan keuangan yang disajikan. Tindakan kecurangan ini dapat merugikan keuangan negara dan bahkan dapat merusak sendi-sendi sosial dalam budaya masyarakat.

Kasus kecurangan yang melibatkan auditor eksternal yang paling terkenal yaitu kasus Enron yang melibatkan KAP Arthur Anderson yang menyatakan laporan keuangan Enron wajar tanpa pengecualian. Namun, pada tanggal 2 desember 2001, publik dikejutkan oleh kabar mengenai kepailitan Enron Corp yaitu diketahui adanya kasus manipulasi laporan keuangan sebesar 600 juta Dolar Amerika Serikat padahal perusahaan mengalami kerugian pada saat itu (Raya, 2016). Enron mampu untuk menyembunyikan kewajiban dan kerugian yang ada sehingga keuntungan dalam 
laporan laba rugi akan menggelembung dan pada akhirnya dapat mengangkat harga saham. Manipulasi keuangan ini dikarenakan perusahaan tetap ingin diminati oleh investor.

Di Indonesia kasus kecurangan yang pernah terjadi pada BUMN salah satunya adalah kasus PT Kimia Farma. Dimana terdapat kesalahan dalam pencatatan laporan keuangan yaitu overstatement pada laba bersih pada tanggal 31 Desember 2001. Dimana manajemen PT Kimia Farma melaporkan laba bersih sebesar Rp132.000.000.000,00 dan diaudit oleh KAP Hans Tuanakotta dan Mustofa (HTM). BAPEPAM dan kementerian BUMN menyatakan bahwa laba bersih tersebut mengandung rekayasa dan terlalu besar. Pada tanggal 3 Oktober 2002 disajikan kembali laporan keuangan yang telah di audit ulang, karena ditemukan adanya kesalahan yang cukup mendasar (Dewi, 2016). Informasi salah saji tersebut terjadi dengan melebih sajikan persediaan dan penjualan pada tiga unit usaha, dan PT Kimia Farma telah menggandakan pencatatan penjualan pada tiga unit usaha yang dilakukan pada unit yang tidak disampling auditor sehingga tidak berhasil dideteksi.

Kasus kecurangan yang lainya terjadi di Daerah Istimewa Yogyakarta pada Kabupaten Sleman yaitu kasus kecurangan korupsi dana hibah KONI (Komite Olahraga Nasional Indonesia) pada tahun anggaran 2010/2011. Setelah tiga kali melakukan pemeriksaan, Kejaksaan Negeri (Kejari) Sleman menetapkan dua orang tersangka. Dari hasil pemeriksaan diketahui kedua tersangka berkerjasama dalam membuat dan merekayasa laporan pertanggungjawaban anggaran KONI, dan kerugian negara pada kasus ini yaitu sebesar Rp917.000.000,00 (Hapsari, 2013).

Penelitian ini merupakan replikasi dari penelitian Hartan dan Waluyo (2016) dan Anggriawan (2014). Dua variabel independen yaitu skeptisme profesional dan independensi diambil dari penelitian Hartan dan Waluyo (2016) yang menguji skeptisme profesional, independensi, dan kompetensi terhadap kemampuan auditor mendeteksi kecurangan pada Inspektorat DIY. Dua variabel pengalaman kerja dan tekanan waktu diambil dari penelitian yang dilakukan oleh Anggriawan (2014) yang menguji pengalaman kerja, skeptisme profesional, dan tekanan waktu terhadap kemampuan auditor dalam mendeteksi fraud pada KAP di DIY. Penelitian kali ini berfokus kepada auditor eksternal yang bekerja pada BPK RI Perwakilan Provinsi Daerah Istimewa Yogyakarta.

\section{TINJAUAN LITERATUR DAN PERUMUSAN HIPOTESIS}

\section{Teori Atribusi}

Teori atribusi menjelaskan mengenai pemahaman atas seseorang tentang mengapa atau apa yang menjadi penyebab dari suatu perilaku individu. Teori ini menjelaskan tentang suatu hubungan sikap dan karakteristik orang lain melalui perilaku yang dimiliki orang lain tersebut. Artinya, kita dapat mengetahui karakteristik dan sikap yang dimiliki individu dari perilaku yang ditunjukkan oleh individu itu sendiri (Ayuningtyas dan Pamudji, 2012).

\section{Teori Kognitif}

Menurut Ibda (2015) teori ini memiliki pandangan bahwa belajar merupakan proses pemfungsian dari unsur-unsur kognisi terutama pada pikiran untuk memahami dan mengenal stimulus yang datang dari luar. Ada tiga prinsip pembelajaran bagi manusia dalam teori kognitif yaitu yang pertama belajar aktif yang berhubungan dengan kemampuan, inisiatif dari individu, dan pengembangan unsur pengetahuan, dan yang kedua belajar melalui interaksi sosial, dan yang ketiga yaitu belajar melalui pengalaman sendiri.

\section{Tekanan Waktu dan Kemampuan Auditor Mendeteksi Kecurangan}

Penelitian yang telah dilakukan oleh Anggriawan (2014) menyatakan bahwa tekanan waktu berpengaruh negatif terhadap kemampuan auditor dalam mendeteksi kecurangan. Hasil penelitian 
menunjukkan bahwa semakin tinggi tekanan waktu yang auditor terima, akan dapat menurunkan kemampuan auditor dalam mendeteksi kecurangan. Pangestika, dkk (2015) dan Arsendy (2017) menunjukkan hasil yang sama yaitu tekanan anggaran waktu berpengaruh negatif terhadap kemampuan seorang auditor dalam melakukan pendeteksian kecurangan.

Tekanan waktu tersebut membuat seorang auditor harus dapat menyesuaikan antara waktu dan tugas yang juga harus diselesaikan. Jika waktu yang telah diestimasikan tidak sesuai dengan waktu yang sebenarnya dibutuhkan, maka seorang auditor cenderung menjadi kurang teliti dan hanya memprioritaskan beberapa tugas saja yang bertujuan agar dalam menyelesaikan tugas waktu yang dibutuhkan sesuai dengan waktu yang telah diestimasikan.

Dapat disimpulkan bahwa semakin tingginya tekanan waktu yang auditor terima, maka akan semakin menurunkan kemampuan seorang auditor dalam melakukan pendeteksian kecurangan. Sehingga didapatkan hipotesis yang pertama, yaitu :

$\boldsymbol{H}_{\mathbf{i}}$ Tekanan waktu berpengaruh negatif terhadap kemampuan auditor mendeteksi kecurangan.

\section{Independensi dan Kemampuan Auditor Mendeteksi Kecurangan}

Penelitian mengenai pengaruh independensi dalam mendeteksi kecurangan sudah banyak peneliti yang melakukan. Seperti pada peneltian Hartan dan Waluyo (2016) yang menunjukkan hasil bahwa independensi berpengaruh positif terhadap kemampuan auditor dalam melakukan pendeteksian kecurangan. Auditor yang mempunyai sikap independensi dan mempertahankannya selama proses audit dan tidak mempedulikan ada atau tidak ada gangguan dan bahkan tekanan dari pihak yang lain maka seorang auditor tersebut mempunyai integritas tinggi. Jadi, semakin tingginya sikap independensi auditor akan semakin membuat peningkatakan terahadap kemampuan seorang auditor dalam mendeteksi kecurangan.

Penelitian Fuad (2015) dan Adnyani dkk (2014) memberikan hasil bahwa independensi mempunyai pengaruh positif terhadap tanggung jawab auditor dalam mendeteksi kecurangan, dan penelitian yang dilakukan Pangestika dkk (2015) juga menunjukkan hasil yang sama bahwa independensi berpangaruh positif terhadap kemampuan auditor dalam mendeteksi kecurangan. Semakin tinggi sikap independensi yang auditor miliki maka akan semakin tinggi tanggung jawab auditor mendeteksi kecurangan. Seorang auditor diharapakan untuk selalu dapat mempertahankan sikap independensi dalam melakukan tugas audit karena apabila sikap independensi dipertahakan maka tanggung jawab seorang auditor dalam mendeteksi kecurangan akan meningkat.

Hubungan antara independensi dan pendeteksian fraud dapat dilihat dari kejujuran yang auditor miliki dalam mempertimbangkan suatu fakta yang ditemui pada saat melakukan kegiatan audit. Sebagai pihak independen, seorang auditor harus mampu memberikan opini berdasarkan fakta dan mengungkapkan temuan yang didapatkan dari laporan keuangan jika terdapat salah saji karena kecurangan atau kekeliruan berdasarkan dengan fakta-fakta yang ada. Berdasarkan yang telah dijelaskan, maka hipotesis yang kedua, yaitu:

\section{$\boldsymbol{H}_{3}$ : Independensi berpengaruh positif terhadap kemampuan auditor mendeteksi kecurangan.}

\section{Skeptisme Profesional dan Kemampuan Auditor Mendeteksi Kecurangan}

Adnyani dkk (2014) dan Arsendy (2017) melakukan penelitian skeptisme profesional audit yang menyatakan hasil yang positif mengenai skeptisme yang auditor miliki dalam kemampuan melakukan pendeteksian kecurangan. Penelitian Kartikarin dan Sugiarto (2016) menunjukkan hasil yang sama yaitu bahwa sikap skeptisme profesional memiliki pengaruh yang positif terhadap kemampuan seorang auditor dalam melakukan pendeteksian kecurangan. Semakin tingginya sikap skeptisme profesional yang auditor miliki, maka semakin akan banyak kemauan atau keinginan untuk mencari tahu terhadap tanda-tanda kecurangan yang ada di sekitarnya. 
Penelitian yang dilakukan Anggriawan (2014) dan penelitian Hartan dan Waluyo (2016) juga menunjukkan bahwa sikap skeptisme profesional memiliki pengaruh yang positif. Seorang auditor dituntut untuk mempunyai sikap skeptisme profesional dalam melakukan tugas auditnya, khususnya untuk kemungkinan terjadinya suatu kecurangan walaupun kecurangan itu belum tentu akan terjadi. Auditor yang memiliki sikap skeptis tidak akan langsung percaya terhadap asersi yang diberikan manajemen. Auditor akan selalu mencari informasi dan bukti tambahan yang bisa dijadikan sebagai pendukung asersi manajemen tersebut. Dengan demikian hipotesis ketiga, yaitu:

\section{$\boldsymbol{H}_{3}$ : Skeptisme profesional berpengaruh positif terhadap kemampuan auditor mendeteksi kecurangan.}

\section{Pengalaman Kerja dan Kemampuan Auditor Mendeteksi Kecurangan}

Penelitian Adnyani dkk (2014) menyatakan bahwa pengalaman kerja berpengaruh signifikan positif terhadap kemampuan auditor dalam mendeteksi kecurangan. Anggriawan (2014) dan Arsendy (2017) juga melakukan penelitian mengenai pengalaman kerja auditor terhadap kemampuan auditor dalam mendeteksi kecurangan dan menunjukkan hasil bahwa pengalaman kerja memiliki pengaruh positif dalam mendeteksi kecurangan.

Semakin lama seorang bekerja sebagai auditor, semakin banyak tugas yang dilakukan, dan semakin banyak perusahaan ditangani, maka auditor tersebut dapat dikatakan sebagai auditor yang berpengalaman. seorang auditor yang memilik pengalaman yang lebih banyak akan menjadikan auditor tersebut lebih paham akan kejadian yang terkait dengan penyebab kekeliruan, apakah kekeliruan tersebut murni karena kesalahan alat atau manusia, dan apakah kekeliruan tersebut terjadi karena kesengajaan yang mengarah pada kecurangan.

Tidak semua auditor memiliki pengalaman yang sama, dan tidak semua auditor dalam melakukan tugasnya menemukan kecurangan. Sehingga kemampuan untuk dapat menemukan kecurangan ditentukan dengan pengetahuan dan pengalaman mengenai kecurangan. Seorang auditor akan mempunyai kemudahan dalam mendeteksi, mencari, dan memahami penyebab dari kesalahan apabila auditor memiliki pengalaman yang lebih banyak. Jadi, semakin tinggi pengalaman kerja yang auditor miliki, maka semakin akan meningkatkan kemampuan auditor dalam mendeteksi kecurangan. Sehingga hipotesis ke empat sebagai berikut:

\section{$\boldsymbol{H}_{4}$ : Pengalaman kerja berpengaruh positif terhadap kemampuan auditor mendeteksi kecurangan.}

\section{METODE PENELITIAN}

Penelitian ini menggunakan jenis data primer, data diperoleh langsung dari sumbernya tanpa ada media perantara. Instrumen penelitian ini berbentuk kuesioner yang berisi pertanyaan mengenai tekanan waktu,independensi, skeptisme profesional, pengalaman kerja, dan kemampuan mendeteksi kecurangan. Penelitian ini dilakukan di kantor BPK RI Perwakilan Provinsi DIY dengan subjek penelitiannya yaitu Pegawai Negeri Sipil (PNS) yang bekerja di BPK tersebut. Pengambilan sampel menggunakan purposive sampling dan non probability sampling yang artinya sampel diambil dengan memperhatikan kriteria yang telah ditentukan yaitu Pegawai Negeri Sipil (PNS) yang bekerja di kantor BPK sebagai auditor eksternal dan pernah menemukan gejala tandatanda kecurangan pada saat melakukan tugas, dan pada penelitian ini tidak memberikan kesempatan yang sama bagi setiap responden. Dengan menggunakan teknik tersebut diperoleh sampel sebanyak 37 responden. 


\section{HASIL DAN PEMBAHASAN}

Kuesioner yang disebarkan ke kantor BPK RI Perwakilan Provinsi DIY sebanyak 45 dengan total kuesioner yang kembali 39 kuesioner. Kuesioner yang dapat diolah sebanyak 37 kuesioner dan 2 kuesioner tidak dapat diolah. Karakteristik responden menyajikan identitas responden yang meliputi: umur responden, jenis kelamin, banyaknya jumlah penugasan, pendidikan terakhir, lama bekerja sebagai auditor, jabatan, pangkat/golongan. Deskripsi karakteristik responden dapat ditunjukan dalam tabel 1:

Tabel 1 Hasil Uji Validitas dan Reliabilitas

\begin{tabular}{|c|c|c|c|}
\hline Keterangan & Deskripsi & Jumlah & Persentase (\%) \\
\hline \multirow[t]{5}{*}{ Umur Responden } & Jumlah Responden & 37 & \\
\hline & $<30$ tahun & - & $0 \%$ \\
\hline & $31-35$ tahun & 8 & $22 \%$ \\
\hline & 36 - 40 tahun & 17 & $46 \%$ \\
\hline & $>40$ tahun & 12 & $32 \%$ \\
\hline \multirow[t]{3}{*}{ Jenis Kelamin } & Jumlah Responden & 37 & \\
\hline & Laki-Laki & 19 & $51 \%$ \\
\hline & Perempuan & 18 & $49 \%$ \\
\hline \multirow[t]{5}{*}{ Pendidikan Terakhir } & Jumlah Responden & 37 & \\
\hline & D3 & - & $0 \%$ \\
\hline & S1 & 28 & $76 \%$ \\
\hline & S2 & 9 & $24 \%$ \\
\hline & S3 & - & $0 \%$ \\
\hline \multirow[t]{5}{*}{ Pangkat/Golongan } & Jumlah Responden & 37 & \\
\hline & III B & 5 & $14 \%$ \\
\hline & III C & 19 & $51 \%$ \\
\hline & III D & 9 & $24 \%$ \\
\hline & IV A & 4 & $11 \%$ \\
\hline Lama Bekerja Menjadi & Jumlah Responden & 37 & \\
\hline \multirow[t]{5}{*}{ Auditor } & $>15$ tahun & 8 & $22 \%$ \\
\hline & $11-15$ tahun & 14 & $38 \%$ \\
\hline & $6-10$ tahun & 15 & $41 \%$ \\
\hline & $1-5$ tahun & - & $0 \%$ \\
\hline & $<1$ tahun & - & $0 \%$ \\
\hline
\end{tabular}

Sumber : Data Primer

\section{Statistik Deskriptif}

Pengujian ini dilakukan untuk memberikan gambaran umum mengenai jumlah sampel, nilai minimum, nilai maximum, mean, dan standar deviasi dari masing-masing variabel yang disajikan sebagai berikut:

Tabel 2 Deskriptif Statistik Data Penelitian

\begin{tabular}{lcrrrr}
\hline & N & \multicolumn{1}{c}{ Minimum } & Maximum & Mean & Std. Deviation \\
\hline KEMAMPUAN AUDITOR & 37 & 2,20 & 4,80 & 3,5297 &, 71603 \\
TEKANAN WAKTU & 37 & 3,67 & 5,00 & 4,2432 &, 48844 \\
INDEPENDENSI & 37 & 3,60 & 5,00 & 4,2216 &, 50724 \\
SKEPTISME PROFESIONAL & 37 & 2,89 & 4,89 & 3,8468 &, 56601 \\
PENGALAMAN KERJA & 37 & 3,70 & 5,00 & 4,2541 &, 48568 \\
Valid N (listwise) & 37 & & & & \\
\hline
\end{tabular}

Sumber : output SPSS 2017

\section{Hasil Pengujian Hipotesis}

Dari hasil pengujian validitas diperoleh bahwa setiap item pernyataan dari seluruh variabel penelitian memiliki nilai pearson correlation > 0,25 sehingga dapat dikatakan kuesioner penelitian 
ini valid. Lima variabel penelitian ini dikatakan reliabel karena memiliki nilai cronbach's alpha masing-masing $>0,7$.

Tabel 3 Uji Asumsi Klasik

\begin{tabular}{|c|c|c|}
\hline \multirow{2}{*}{$\begin{array}{r}\text { Kolmogorof-Smirnov } \\
\text { Variabel }\end{array}$} & \multicolumn{2}{|c|}{,565 } \\
\hline & Tolerance & VIF \\
\hline Tekanan Waktu &, 355 & 3,234 \\
\hline Independensi & 445 & 2,136 \\
\hline Skeptisme Profeisonal & 493 & 2,542 \\
\hline Pengalaman Kerja & ,226 & 4,641 \\
\hline Variabel & & Sig \\
\hline Tekanan Waktu & &, 528 \\
\hline Independensi & & ,095 \\
\hline Skeptisme Profeisonal & & ,232 \\
\hline Pengalaman Kerja & & 121 \\
\hline
\end{tabular}

Sumber : output SPSS 2017

Setelah dilakukan uji asumsi klasik dapat disimpulkan bahwa data terdistribusi secara normal, tidak mengandung multikolinearitas dan tidak terdapat heteroskedastisitas, maka dapat dilakukan uji regresi linear berganda. Pengujian regresi linear berganda dilakukan untuk mengetahui apakah variabel tekanan waktu, independensi, skeptisme profesional, dan pengalaman kerja berpengaruh terhadap kemampuan auditor mendeteksi kecurangan.

Tabel 4 Hasil Pengujian Hipotesis

\begin{tabular}{lccc}
\hline \multicolumn{1}{c}{ Variabel } & B & Sig & Keterangan \\
\hline Tekanan Waktu &,- 597 & 0,35 & Berpengaruh \\
Independensi &, 306 & 0,12 & Berpengaruh \\
Skeptisme Profeisonal &, 499 & 0,10 & Berpengaruh \\
Pengalaman Kerja &, 135 & 0,17 & Berpengaruh \\
Adjusted R Square & & &, 964 \\
F Statistic & & & 245,115 \\
Prob (F Statistik) & & &, 000 \\
\hline
\end{tabular}

Sumber : output SPSS 2017

\section{Pengaruh Tekanan Waktu Terhadap Kemampuan Auditor Mendeteksi Kecurangan}

Hasil pengujian terhadap hipotesis menunjukkan bahwa Hipotesis 1 diterima yang artinya tekanan waktu berpengaruh negatif terhadap kemampuan auditor dalam mendeteksi kecurangan. Hasil penelitian ini konsisten dengan penelitian yang dilakukan oleh Anggriawan (2014) dan Pangestika, dkk (2015) yang menyatakan bahwa tekanan waktu memiliki pengaruh yang negatif terhadap kemampuan auditor dalam melakukan pendeteksian kecurangan. Arsendy (2017) melakukan penelitian dengan menyatakan hasil yang sama bahwa tekanan waktu berpengaruh negatif terhadap kemampuan auditor dalam mendeteksi kecurangan. Sehingga semakin rendah tekanan waktu yang auditor terima, maka akan semakin tinggi kemampuan auditor dalam melakukan pendeteksian kecurangan.

Tekanan waktu akan membuat auditor mempunyai masa sibuk untuk dapat menyelesaikan tugasnya secara tepat waktu. Tekanan waktu juga akan dapat menurunkan tingkat sensitivitas terhadap salah saji yang ada baik karena kecurangan maupun kekeliruan, hal ini disebabkan karena auditor hanya fokus terhadap pekerjaan yang harus diselesaikan, maka auditor akan gagal dalam mendeteksi kecurangan. Auditor bekerja cenderung tidak teliti dan kemungkinan mengabaikan beberapa hal kecil, dimana hal ini akan menyebabkan menurunnya tingkat keakuratan dan keyakinan dari laporan keuangan, bahkan dengan adanya tekanan waktu maka akan mengakibatkan kegagalan auditor dalam mendeteksi kecurangan karena ketidaktelitiannya terhadap tanda ataupun gejala dari adanya suatu kecurangan. 


\section{Pengaruh Independensi Terhadap Kemampuan Auditor Mendeteksi Kecurangan}

Hasil pengujian hipotesis menyatakan bahwa Hipotesis 2 diterima, hal ini menunjukkan bahwa independensi memiliki pengaruh positif terhadap kemampuan auditor dalam mendeteksi kecurangan. Oleh karena itu, semakin tinggi independensi yang dimiliki oleh auditor, maka kemampuan auditor mendeteksi kecurangan dalam laporan keuangan juga semakin tinggi. Hal ini konsisten dengan hasil penelitian yang dilakukan oleh Hartan dan Waluyo (2016), Fuad (2015), dan Pangestika, dkk (2015) yang menyatakan bahwa independensi memiliki pengaruh yang positif terhadap kemampuan auditor dalam melakukan pendeteksian kecurangan.

Menurut Fuad (2015) independensi dapat menjadikan auditor lebih mengutamakan kejujuran terlebih dalam mempertimbangkan suatu fakta secara objektif dan tidak memihak dalam memberikan opini. Sehingga auditor yang memiliki independensi tinggi, apabila menemukan kecurangan dalam kegiatan auditnya, auditor akan mengungkapkan temuan tersebut dan tidak memihak terhadap siapapun. Maka independensi menjadi faktor yang dapat mempengaruhi kemampuan auditor dalam mendeteksi kecurangan.

\section{Pengaruh Skeptisme Profesional Terrhadap Kemampuan Auditor Mendeteksi Kecurangan}

Hasil pengujian terhadap hipotesis menyatakan bahwa Hipotesis 3 diterima, hal ini berarti skeptisme profesional berpengaruh positif terhadap kemampuan auditor dalam mendeteksi kecurangan, semakin tinggi skeptisme profesional yang auditor miliki maka akan semakin tinggi kemampuan auditor dalam mendeteksi kecurangan, dan pernyataan ini konsisten dengan hasil penelitian yang dilakukan oleh Arsendy (2017), Hartan dan Waluyo (2016), Kartikarin dan Sugiarto (2016), Anggriawan (2014), dan Adnyani, dkk (2014) yang menyatakan hasil bahwa skeptisme profesional mempunyai pengaruh yang positif terhadap kemampuan auditor dalam mendeteksi kecurangan.

Auditor yang mempunyai sikap skeptisme profesional dalam membuat keputusan dan memberikan opininya akan lebih berhati-hati, auditor juga akan mencari informasi dan bukti tambahan guna memastikan bahwa laporan keuangan yang diaudit terbebas dari segala bentuk salah saji. Ukuran kinerja auditor dapat dikatakan baik jika mampu memperoleh kayakinan dalam laporan keuangan yang diauditnya terbebas dari salah saji. Oleh karena itu, skeptisme profesional auditor dapat meningkatkan kualitas laporan keuangan audit. Hal ini menunjukkan bahwa skeptisme profesional menjadi faktor yang dapat mempengaruhi kemampuan auditor dalam mendeteksi kecurangan.

\section{Pengaruh Pengalaman Kerja Terhadap Kemampuan Auditor Mendeteksi Kecurangan}

Hasil pengujian terhadap hipotesis menunjukkan hasil bahwa Hipotesis 4 diterima, yang artinya pengalaman kerja memiliki pengaruh yang positif terhadap kemampuan auditor dalam mendeteksi kecurangan. Hal ini konsisten dengan hasil penelitian yang dilakukan oleh Arsendy (2017), Anggriawan (2014), dan Adnyani, dkk (2014) yang menyatakan hasil bahwa pengalaman kerja auditor berpengaruh positif terhadap kemampuan auditor dalam melakukan pendeteksian kecurangan.

Auditor yang mempunyai banyak pengalaman dalam kegiatan auditnya akan memiliki banyak hal yang bisa meningkatkan kemampuan, pengetahuan, dan keahliannya dalam mendeteksi kecurangan apabila dibandingkan dengan auditor yang kurang atau sedikit mempunyai pengalaman. Semakin berpengalaman auditor, kemampuan auditor tersebut juga akan semakin tinggi atau baik dalam melakukan pendeteksian kecurangan. Seorang auditor dapat dikatakan berpengalaman apabila ia telah lama bekerja sebagai auditor dan semakin banyak penugasan yang ditangani, sehingga auditor akan mempunyai banyak pengetahuan yang dapat meningkatkan kepekaan dan kesadarannya apabila terjadi kecurangan. Pengalaman yang auditor miliki akan meningkatkan pemahamannya terhadap penyebab kecurangan, sehingga akan dapat memudahkan auditor dalam 
mendeteksi kecurangan. Hal ini menunjukkan bahwa pengalaman kerja dapat menjadi faktor yang mempengaruhi kemampuan auditor dalam mendeteksi kecurangan.

\section{KETERBATASAN PENELITIAN}

Penelitian ini memiliki beberapa keterbatasan yaitu penelitian ini hanya menggunakan sampel auditor eksternal pemerintah yang bekerja di BPK RI Perwakilan Provinsi Yogyakarta saja. Sehingga hanya mewakili tingkat kemampuan auditor dalam mendeteksi kecurangan di wilayah Yogyakarta. Penelitian ini variabel yang mempengaruhi kemampuan auditor dalam mendeteksi kecurangan hanya terbatas pada variabel tekanan waktu, independensi, skeptisme profesional, dan pengalaman kerja saja. Oleh karena itu, untuk penelitian selanjutnya diharapkan dapat menambah jumlah variabel lain seperti gender, budaya organisasi, pendidikan, dan lainnya.

\section{KESIMPULAN}

Berdasarkan pengujian dan analisis yang telah dilakukan maka kesimpulan dari penelitian ini adalah bahwa tekanan waktu memiliki pengaruh yang negatif terhadap kemampuan auditor dalam mendeteksi kecurangan pada laporan keuangan. Independensi, skeptisme profesional, dan pengalaman kerja memiliki pengaruh yang positif terhadap kemampuan auditor dalam mendeteksi kecurangan pada laporan keuangan.

Dengan adanya keterbatasan dalam penelitian ini, maka saran yang dapat diberikan untuk memperbaiki penelitian selanjutnya adalah memperluas wilayah sampel penelitian agar dapat digeneralisasikan yakni tidak hanya auditor yang bekerja pada BPK RI Perwakilan Provinsi Yogyakarta saja, tetapi bisa menambah sampel auditor yang bekerja BPK Perwakilan Provinsi lainnya. Menambah variabel penelitian yang mempengaruhi kemampuan auditor dalam mendeteksi kecurangan. Sehingga dapat memperluas penelitian baru mengenai faktor-faktor yang dapat mempengaruhi kemampuan auditor dalam mendeteksi kecurangan seperti gender, budaya organisasi, pendidikan, dan lainnya.

\section{DAFTAR PUSTAKA}

Adnyani, N., Atmadja, A. T., Herawati, N. T., \& AK, S. (2014). Pengaruh Skeptisme Profesional Auditor, Independensi, dan Pengalaman Auditor Terhadap Tanggungjawab Auditor dalam Mendeteksi Kecurangan dan Kekeliruan Laporan Keuangan. Jurnal Ilmiah Mahasiswa Akuntansi S1,2(1).

Al-Quran dan Terjemahannya. (2014). Jakarta: Departemen Agama RI.

Anggriawan, E.F. (2014). Pengaruh Pengalaman Kerja, Skeptisme Profesional dan Tekanan Waktu Terhadap Kemampuan Auditor dalam Mendeteksi Fraud. Jurnal Nominal / Volume III, 2.

Arsendy, M. T. (2017). Pengaruh Pengalaman Audit, Skeptisme Profesional, Red Flags, dan Tekanan Anggaran Waktu Terhadap Kemampuan Auditor Dalam Mendeteksi Kecurangan. Jurnal Online Mahasiswa (JOM)Fekon, 4, 1.

Asih, D. A. T. (2006). Pengaruh Pengalaman Terhadap Peningkatan Keahlian Auditor dalam Bidang Auditing. Skripsi. Universitas Islam Indonesia. Yogyakarta.

Aulia, M. Y. (2013). Pengaruh Pengalaman, Independensi dan Skeptisme Profesional Auditor Terhadap Pendeteksian Kecurangan. Skripsi. Fakultas Ekonomi. Universitas Islam Negeri Syarif Hidayatullah. Jakarta

Ayuningtyas, H. Y., \& Pamudji, S. (2012). Pengaruh Pengalaman Kerja, Independensi, Obyektifitas, Integritas Dan Kompetensi Terhadap Kualitas Hasil Audit. Skripsi. Semarang: Penerbit Universitas Diponegoro. 
Dewi, M. (2016). Pengaruh Red Flags, Whistleblowing, dan Profesionalisme Auditor Internal Terhadap Pendeteksian Kecurangan Laporan Keuangan (Bachelor's thesis, Jakarta: Fakultas Ekonomi dan Bisnis UIN Syarif Hidayatullah Jakarta).

Fuad, K. (2015). Pengaruh Independensi, Kompetensi, dan Prosedur Audit Terhadap Tanggung Jawab Dalam Pendeteksian Fraud. Jurnal Dinamika Akuntansi, 7(1).

Gusti \& Ali. (2008). Hubungan Skeptisisme Profesional Auditor Dan Situasi Audit, Etika, Pengalaman Serta Keahlian Audit Dengan Ketepatan Pemberian Opini Auditor Oleh Akuntan Publik. Padang: Jurnal Simposium Nasional Akuntansi, 8.

Hapsari, A. (2013). Dua Tersangka Korupsi Koni Sleman Ditahan. Didapat dari: www.suaramerdeka.com

Hartan, T. H., \& Waluyo, I. (2016). Pengaruh Skeptisme Profesional, Independensi, dan Kompetensi Terhadap Kemampuan Auditor Mendeteksi Kecurangan. Jurnal Profita: Kajian Ilmu Akuntansi, 4(3).

Ibda, F. (2015). Perkembangan Kognitif: Teori Jean Piaget. Intelektualita, 3(1).

Kartikarin, N., Sugiarto, D., \& Acc, M. (2016). Pengaruh Gender, Keahlian, dan Skeptisisme Profesional terhadap Kemampuan Auditor Mendeteksi Kecurangan (Studi pada Badan Pemeriksa Keuangan Republik Indonesia).

Koroy, T. M. (2008). Pendeteksian Kecurangan (Fraud) Laporan Keuangan oleh Auditor Eksternal. Jurnal Akuntansi dan Keuangan. 10 (1), 22- 33.

Liana, L. (2009). Penggunaan MRA dengan Spss untuk Menguji Pengaruh Variabel Moderating terhadap Hubungan antara Variabel Independen dan Variabel Dependen. Dinamik-Jurnal Teknologi Informasi, 14(2).

Nazaruddin, I., \& Basuki, A. T. (2015). Analisis Statistik dengan SPSS. Sleman: Dianisa Media.

Noviyani, P., \& Bandi. (2002). Pengaruh Pengalaman dan Pelatihan Terhadap Struktur Pengetahuan Auditor Tentang Kekeliruan. Simposium Nasional Akuntansi 5, 481-488.

Noviyanti, S. (2008). Skeptisme Profesional Auditor Dalam Mendeteksi Kecurangan. Jurnal Akuntansi dan Keuangan Indonesia, 5(1), 102-125.

Nugraha, A. E. P. (2012). Pengaruh Kompetensi, Tekanan Waktu, Pengalaman Kerja, Etika dan Independensi Auditor Terhadap Kualitas Audit. Skripsi. Fakultas Ekonomi Universitas Negeri Yogyakarta

Octavia, L. (2014). Pengaruh Skeptisme Profeional, Pelatihan Audit Kecurangan, dan Independensi Terhadap Kemampuan Auditor Dalam Mendeteksi Kecurangan (Studi di Inspektorat Kabupaten Sleman). Skripsi. Universitas Gajah Mada. Yogyakarta.

Pangestika, W., Taufik, T., \& Silfi, A. (2015). Pengaruh Keahlian Profesional, Independensi, dan Tekanan Anggaran Waktu terhadap Pendeteksian Kecurangan (Studi Empiris pada Badan Pemeriksa Keuangan Perwakilan Provinsi Riau). Jurnal Online Mahasiswa (JOM) Bidang Ilmu Ekonomi, 1(2), 1-15.

Raya, C. I. (2016). Pengaruh Independensi Dan Skeptisisme Profesional Auditor Terhadap Pendeteksian Kecurangan (Fraud)(Studi Pada Auditor Pemerintah Di Perwakilan Bpkp Provinsi Sul-Sel). Skripsi. Universitas Hasanuddin. Makassar.

Sawyer, L. B. (2006). Sawyer's Internal Auditing. The Practice of Modern Internal Auditing. Diterjemahkan oleh Desi Adhariani. Buku 2. Edisi 5. Jakarta : Salemba Empat.

Simanjuntak, S. N. (2015). Pengaruh Independensi, Kompetensi, Skeptisme Profesional dan Profesionalisme Terhadap Kemampuan Mendeteksi Kecurangan (Fraud) pada Auditor di BPK RI Perwakilan Provinsi Sumatera Utara. Jom FEKON 2 (2) Oktober.

Sososutikno, C. (2003). Hubungan Tekanan Anggaran Waktu dengan Perilaku Disfungsional serta Pengaruhnya terhadap kualitas Audit. Surabaya: Simposium Nasional Akuntansi VI.

Sukirman \& Sari, M.P. (2013). Model Deteksi Kecurangan Berbasis Fraud Triangle. Jurnal Akuntansi \& Auditing. Volume 9(2).

Sukriah, I., Akram \& Inapty, B. A. (2009). Pengaruh Pengalaman Kerja, Independensi, Obyektifitas, Integritas, dan Kompetensi Terhadap Kualitas Hasil Pemeriksaan. SNA 12 Palembang: Penerbit Universitas Sriwijaya. 
Taufik, W. (2008). Pengaruh pengalaman kerja dan pendidikan profesi auditor internal terhadap kemampuan mendeteksi fraud. Jakarta: Penerbit Universitas Islam Negeri Syarif Hidayatullah.

Undang-undang Republik Indonesia. 2004. Undang-undang No. 15 tentang Badan Pemeriksaan Keuangan. Lembaran Negara RI. Jakarta

Undang-undang Republik Indonesia. 2004. Undang-undang pasal 23E ayat 1 dan 2 tentang Badan Pemeriksaan Keuangan. Lembaran Negara RI. Jakarta

Undang-undang Republik Indonesia. 2006. Undang-undang pasal 1 ayat 11 tentang Badan Pemeriksaan Keuangan. Lembaga Negara RI. Jakarta

Widiyastuti, M. \& Pamudji, S. (2009). Pengaruh Kompetensi, Independensi, dan Profesionalisme Terhadap Kemampuan Auditor Dalam Mendeteksi Kecurangan (Fraud). Jurnal, 5 (2). Fakultas Ekonomi Universitas Diponegoro Semarang.

Wusqo, U. (2016). Pengaruh Beban Kerja, Independensi, Skeptisme Profesional, dan Pengalaman Audit Terhadap Kemampuan Auditor dalam Mendeteksi Kecurangan. Skripsi. Fakultas Ekonomi Universitas Muhammadiyah Yogyakarta. 